\title{
Identifikasi Boraks pada Cincau Hitam yang Diproduksi Beberapa Produsen Cincau Hitam di Kota Padang
}

\author{
Rana Zara Athaya ${ }^{1}$, Elmatris ${ }^{2}$, Husnil Kadri ${ }^{3}$
}

\begin{abstract}
Abstrak
Keamanan makanan merupakan salah satu masalah yang harus mendapatkan perhatian terutama di negara berkembang, karena dapat berdampak buruk bagi kesehatan. Penyebabnya adalah masih rendahnya ilmu pengetahuan dan tanggung jawab produsen pangan terhadap mutu dan keamanan makanan terutama pada industri rumah tangga. Salah satunya adalah produsen cincau hitam (Mesona palustris BI.). Hal ini menyebabkan produsen sering menambahkan bahan kimia ke dalam produk makanan, seperti boraks. Konsumsi boraks dapat menyebabkan mual, muntah, kanker, bahkan kematian. Tujuan penelitian ini adalah melakukan identifikasi dan penentuan kadar boraks pada cincau hitam yang diproduksi beberapa produsen di kota Padang. Penelitian ini merupakan studi deskriptif dengan teknik total sampling. Telah diteliti 18 sampel cincau hitam dari produsen berbeda yang dikumpulkan dari beberapa pasar tradisional yang ada di kota Padang. Pemeriksaan kualitatif dilakukan dengan menggunakan Test Kit Boraks yang terdiri atas cairan pereaksi dan kertas uji turmerik. Hasil penelitian menunjukkan bahwa 16 sampel dari 18 sampel yang diidentifikasi positif mengandung boraks $(88,89)$. Berdasarkan hasil yang didapatkan dapat disimpulkan bahwa hampir seluruh produsen cincau hitam menggunakan boraks pada produk mereka.
\end{abstract}

Kata kunci: boraks, cincau hitam, produsen

\section{Abstract}

The food safety is one of problems that should get attention, especially in developing countries, because it can gives a negative impact for the health. The cause is lack of knowledge and responsibility for the quality and safety of food, especially in home industry like black grass jelly (Mesona palustris BI) producer. It causes producers often add chemicals to food products, one of them is borax. Consumption of borax can cause nausea, vomiting, cancer, adn even death. The objective of this study was to identify borax in black grass jelly. This descriptive study using total sampling technique There were 18 black grass jellies from different producers were collected from some traditional market in Padang. The qualitative examination done by using the borax test kit that contain of reagen and turmeric paper color. The results show that 16 black grass jellies from 18 samples (88,89\%) are positive contain borax. It can be conclude that almost of the black grass jellies producer in Padang has been used borax in their product.

Keywords: borax, black grass jelly, producer

Affiliasi penulis: 1. Prodi Profesi Dokter FK Unand (Fakultas Kedokteran Universitas Andalas Padang), 2. Bagian Kimia FK Unand, 3. Bagian Biokimia FK Unand.

Korespondensi: Rana Zara Athaya, Email: asarond@gmail.com Telp: +6281320002134

\section{PENDAHULUAN}

Ancaman penyakit degeneratif seperti tekanan darah tinggi (hipertensi), penyakit kencing manis (diabetes melitus), kadar trigliserida tinggi (hipertrigliseridemia), kadar kolesterol tinggi (hiper- 
kolesterolemia) dan kanker membuat masyarakat membutuhkan tanaman obat yang dapat meningkatkan daya tahan tubuh (imunitas), meningkatkan vitalitas tubuh, pengobatan penyakit infeksi, maupun pengobatan penyakit degeneratif. Salah satu bentuk produk yang diyakini manfaat kesehatannya bagi tubuh selain dari karakteristiknya yang menarik adalah minuman herbal. ${ }^{1}$

Minuman herbal menjadi terkenal karena aroma, kandungan antioksidan dan aplikasinya dalam bidang kesehatan. Tren pemanfaatan keanekaragaman tanaman hayati untuk pengobatan herbal secara alami berdasarkan praktek empiris di Indonesia semakin meningkat. Jenis tanaman herbal yang berpotensi sebagai bahan baku minuman herbal salah satunya adalah cincau hitam (Mesona palustris $\mathrm{BI}$ ), karena selain ketersediaannya di Indonesia yang tinggi, cincau hitam juga telah diteliti memiliki beberapa senyawa bioaktif yang bermanfaat bagi tubuh diantaranya adalah senyawa polifenol, alkaloid, sinamaldehid dan lain-lain. Cincau hitam sebagai bahan baku minuman herbal dapat menjadi alternatif minuman fungsional yang diharapkan dapat membantu mengatasi penyakit degeneratif. ${ }^{2,3}$

Cincau hitam merupakan bahan makanan tradisional yang telah lama dikenal masyarakat dan digunakan sebagai isi minuman segar. Biasanya konsumen menyukai cincau hitam dengan konsistensi kenyal, kokoh dan kuat. Bahan pengawet makanan sebenarnya tidak diperlukan dalam pembuatan cincau, namun masih dimungkinkan para produsen cincau menambahkan bahan pengawet dengan harapan produknya tidak mudah rusak ketika dipasarkan. Ada beberapa artikel maupun berita yang memaparkan beberapa kasus ditemukannya kandungan boraks dalam cincau hitam. ${ }^{4}$

Asam borat (borid acid) dan boraks merupakan zat pengawet berbahaya yang tidak diizinkan digunakan sebagai campuran bahan makanan. Boraks adalah senyawa kimia berbentuk kristal putih, tidak berbau dan stabil pada suhu dan tekanan normal. Dalam air, boraks berubah menjadi natrium hidroksida dan asam borat. Asam borat dan turunannya merupakan senyawa kimia yang mempunyai sifat karsinogen. ${ }^{5,6}$
Asam boraks dan turunannya merupakan salah satu dari jenis bahan tambahan makanan yang dilarang digunakan dalam produk makanan. pemakaian boraks dalam makanan tidak diperbolehkan dalam kadar apapun. Boraks dinyatakan dapat mengganggu kesehatan bila digunakan dalam makanan. ${ }^{7}$

Boraks merupakan bahan yang dikenal dalam industri farmasi sebagai ramuan obat misalnya salep, bedak, larutan kompres, obat oles mulut dan obat pencuci mata. Jika boraks terdapat pada makanan maka dalam jangka waktu yang lama akan menumpuk pada otak, hati, lemak, dan ginjal. Pemakaian dalam jumlah yang banyak dapat menyebabkan demam, depresi, kerusakan ginjal, nafsu makan berkurang, gangguan pencernaan, kebodohan, kebingungan, radang kulit, anemia, kejang, pingsan, bahkan kematian. ${ }^{8}$

Meskipun boraks berbahaya bagi kesehatan ternyata masih banyak digunakan oleh masyarakat sebagai bahan tambahan makanan, karena selain berfungsi sebagai pengawet, boraks juga dapat memperbaiki tekstur makanan hingga lebih kenyal dan lebih disukai konsumen, salah satunya cincau hitam. ${ }^{9}$

Cincau hitam merupakan makanan populer dan mudah diperoleh dimana saja mulai dari rumah makan, warung, hingga pasar tradisional maka peneliti berminat untuk melakukan penelitian terhadap beberapa produsen cincau hitam yang ada di Kota Padang. Sampel yang digunakan akan diambil dari produsen cincau hitam yang ada di Kota Padang. Studi ini akan meneliti kandungan boraks dalam cincau yang diambil dari beberapa produsen tersebut.

\section{METODE}

Jenis penelitian ini merupakan studi deskriptif yang proses identifikasinya dilakukan di Laboratorium Kimia Fakultas Kedokteran Universitas Andalas Padang dari Februari 2015 sampai Juni 2015. Sampel pada penelitian ini adalah cincau hitam yang diproduksi oleh 18 produsen cincau hitam di kota Padang. Pengambilan sampel dilakukan dibeberapa pasar tradisional yang ada di Kota Padang yaitu Pasar Raya, Pasar Pagi, Pasar Tanah Kongsi, Pasar Lubuk 
Buaya, Pasar Siteba, Pasar Alai, Pasar Belimbing, dan Pasar Bandar Buat.

Pengambilan sampel dilakukan dengan teknik total sampling. Pemeriksaan sampel menggunakan Metode Easy Test Boraks

HASIL

Tabel 1. Identifikasi boraks pada cincau hitam yang diproduksi beberapa produsen di Kota Padang

\begin{tabular}{lll}
\hline No & Sampel & Identifikasi \\
\hline 1 & S1 & Teridentifikasi \\
2 & S2 & Teridentifikasi \\
3 & S3 & Teridentifikasi \\
4 & S4 & Teridentifikasi \\
5 & S5 & Teridentifikasi \\
6 & S6 & Tidak teridentifikasi \\
7 & S7 & Teridentifikasi \\
8 & S & Tidak teridentifikasi \\
9 & S9 & Teridentifikasi \\
10 & S10 & Teridentifikasi \\
11 & $\mathrm{~S} 11$ & Teridentifikasi \\
12 & $\mathrm{~S} 12$ & Teridentifikasi \\
13 & $\mathrm{~S} 13$ & Teridentifikasi \\
14 & $\mathrm{~S} 14$ & Teridentifikasi \\
15 & $\mathrm{~S} 15$ & Teridentifikasi \\
16 & $\mathrm{~S} 16$ & Teridentifikasi \\
17 & $\mathrm{~S} 17$ & Teridentifikasi \\
18 & $\mathrm{~S} 18$ & Teridentifikasi \\
\hline
\end{tabular}

Dari 18 sampel cincau hitam yang sudah diidentifikasi boraks dapat dilihat bahwa ada 16 sampel cincau hitam positif mengandung boraks $(88,89 \%)$.

\section{PEMBAHASAN}

Berdasarkan hasil penelitian yang telah dilakukan pada 18 sampel cincau hitam dilaboratorium Kimia Fakultas Kedokteran Universitas Andalas ternyata $88,89 \%$ cincau hitam teridentifikasi mengandung boraks.

Penggunaan boraks sebagai tambahan pangan dilarang dan sudah tertuang dalam peraturan Menteri Kesehatan dengan acuan UU No.23/1992 tentang kesehatan yang menekankan aspek keamanan dan UU No.7/1996 tentang pangan, hampir semua sampel yang telah diuji mengandung boraks. Hal ini mungkin disebabkan oleh masih rendahnya pengetahuan dan tanggung jawab produsen cincau hitam terhadap mutu dan keamanan cincau hitam yang diproduksinya. ${ }^{10,11}$

Sesuai dengan pengamatan dilapangan ciri-ciri cincau hitam yang mengandung boraks memang hampir sama dengan cincau hitam yang tidak mengandung boraks, namun jika diamati dengan seksama cincau hitam yang mengandung boraks memiliki ciri-ciri fisik yang berbeda dengan cincau hitam yang tidak mengandung boraks. Penelitian ini menemukan bahwa cincau hitam yang mengandung boraks konsistensinya lebih padat, kenyal, dan lebih susah dihancurkan dibandingkan dengan cincau hitam yang tidak mengandung boraks. Sedangkan cincau hitam yang tidak mengandung boraks biasanya mempunyai bentuk yang kurang bagus dan mudah hancu. Hal ini dikarenakan boraks memiliki khasiat antiseptika yang menghambat pertumbuhan dan perkembangan mikroorganisme. Boraks juga merupakan senyawa yang terbukti dapat memperbaiki tekstur makanan, sehingga menghasilkan bentuk pangan yang bagus. Boraks yang seharusnya bukan untuk pangan ini sering kali disalahgunakan untuk mengolah pangan. ${ }^{12,13}$

Di Kota Padang penyalahgunaan pemakaian boraks sudah marak sejak lama. Berdasarkan hasil penelitian yang dilakukan di beberapa pasar di kota Padang tahun 2006 didapatkan, 5 sampel dari 10 sampel mie basah yang diteliti mengandung boraks.Selain itu, laporan dari BPOM Padang juga didapatkan adanya boraks di dalam kerupuk nasi. ${ }^{14}$

Pelanggaran para produsen terhadap berbagai peraturan perundangan tidak hanya disebabkan oleh rendahnya pengetahuan dan tanggung jawab produsen terhadap mutu dan keamanan pangan yang diproduksinya saja, tetapi juga dapat disebabkan oleh faktor kurangnya pengetahuan mengenai peraturan dan kesadaran terhadap hukum. Padahal, sanksi yang diterapkan pada mereka yang menggunakan bahan berbahaya berdasarkan pasal 55 UU Pangan cukup berat, yaitu hukuman penjara maksimal 5 (lima) tahun atau didenda maksimal enam ratus juta rupiah. ${ }^{15}$

Manusia yang mengonsumsi makanan yang mengandung boraks dapat mengakibatkan toksik (keracunan), gangguan otak, hati, lemak dan ginjal. Gejala dapat berupa mual, muntah, diare, suhu tubuh 
menurun, lemah, sakit kepala, bahkan dapat menimbulkan syok. Pada anak-anak dalam masa pertumbuhan, adanya bahan boraks dapat meracuni pertumbuhan sel-sel otak hingga menyebabkan gangguan kecerdasan dan intelektual. ${ }^{16}$

\section{SIMPULAN}

Berdasarkan penelitian yang telah dilakukan terhadap 18 sampel cincau hitam yang dijual pada beberapa pasar di Kota Padang dan diproduksi oleh 18 produsen yang berbeda didapatkan 16 sampel cincau hitam dinyatakan positif mengandung boraks.

\section{UCAPAN TERIMAKASIH}

Terimakasih kepada responden di beberapa pasar tradisional di Kota Padang yaitu Pasar Raya, Pasar Pagi, Pasar Tanah Kongsi, Pasar Lubuk Buaya, Pasar Siteba, Pasar Alai, Pasar Belimbing, dan Pasar Bandar Buat yang telah membantu dalam mengumpulkan sampel dan juga terima kasih kepada Ketua Laboratorium Kimia Fakultas Kedokteran Universitas Andalas beserta staf yang telah mengizinkan dan membantu penulis dalam melakukan dan menyelesaikan penelitian.

\section{DAFTAR PUSTAKA}

1. Siah WM, Azman MA, Jeeven K, Noor Hayazan M.D, Mohd Tahir S. Effect of infusion conditions on total phenolic content and antioxidant activity in centella asiatica. 2011;39(2):149-56.

2. Chiang CE, Eng SY, Tan YP, Tan LN.. Antioxidant and sensory properties of thai herbal teas with emphasis on thunbergia laurifolia. Lindl. Chiang Mai J. 2012;39(4):599-609.

3. Tasia WRN, Widyaningsih TD. Potensi cincau hitam sebagai minuman herbal fungsional. Jurnal Pangan Dan Agroindustry. 2014;2(4):128-36.
4. Pitojo S, Zumiati. Cincau cara pembuatan dan variasi olahannya. Tangerang: PT Agromedia Pustaka; 2005.

5. Syah D. Manfaat dan bahaya tambahan pangan. Jakarta: Himpunan Alumni Fakultas Tekhnologi Pertanian IPB; 2005.

6. Sugiyatmi S. Analisis faktor-faktor risiko pencemaran bahan toksik boraks dan pewarna pada makanan jajanan tradisional yang dijual di pasar-pasar kota Semarang tahun 2006. Penelitian; 2006.

7. Nevrianto R. Ancaman boraks lewat bakso. Jakarta: PT Grafiti Pers; 1991.

8. Karim S. Belajar IPA. Jakarta: PT Begawan IImu; 2008.

9. Aminah MS, Himawan C. Bahan-bahan berbahaya dalam kehidupan. Bandung: Salamadani; 2009.

10. Sekretariat Negara Republik Indonesia. UndangUndang No. 23 Tahun 1992 tentang Kesehatan. Jakarta: Sekretariat Negara; 1992.

11. Sekretariat Negara Republik Indonesia. UndangUndang No. 7 Tahun 1996 tentang Pangan. Jakarta: Sekretariat Negara; 1996.

12. Khamid, IR. Bahaya Boraks Bagi Kesehatan. Jakarta: Penerbit Kompas; 2006.

13. Wijaya D. Waspadai zat aditif dalam makananmu. Yogyakarta: Buku biru; 2011.

14. Asterina, Elmatris, Endrinaldi. Ringkasan identifikasi dan penetapan kadar boraks pada mie basah yang beredar di beberapa pasar di kota Padang. Penelitian; 2006.

15. Sekretariat Negara Republik Indonesia. UndangUndang No. 7 Tahun 1996 tentang Pangan pasal 55. Jakarta: Sekretariat Negara; 1996.

16. Cahyadi W. Kajian dan analisis bahan tambahan pangan. Edisi ke-1. Jakarta: Bumi Aksara; 2006. 